\title{
Gallbladder Cancer pNX TNM Finding v8
}

National Cancer Institute

\section{Source}

National Cancer Institute. Gallbladder Cancer pNX TNM Finding v8. NCI Thesaurus. Code C134656.

Gallbladder cancer in which the regional lymph nodes cannot be assessed. (from AJCC 8th Ed.) 